\author{
Jenny Aimers and Peter Walker
}

Dr Peter Walker is a Senior Lecturer in the Department of Sociology, Gender and Social Work at the University of Otago. He has a background in the community and voluntary sector, most notably with the Community Law Centres. He is currently serving in a governance capacity for the Dunedin Community Law Centre and the Dunedin Community Accounting Centre.

Jenny Aimers is the Research Co-ordinator at Otago Polytechnic. She has a background as a community worker for a diverse range of groups from the Taieri Social Services Council to the YWCA of Dunedin, and also as a Community Advisor for the Dunedin City Council.

Both Peter and Jenny are currently involved in the co-ordination of a multi-disciplinary Community Research Forum for the Dunedin area in conjunction with ANGOA and the Dunedin Council of Social Services and other researchers with an interest in community-based research. The purpose of the forum is to disseminate research within the community and encourage community organisations to develop their own research capabilities.

\begin{abstract}
Community development is a core subject in social work education, yet social work discourse often places community development at its margins (Mendes, 2009). This article considers the location of community development and community work within the current neoliberal environment in New Zealand and how such practice can be sustained by social workers in the community and voluntary sector.

Community development is a way of working with communities that has a 'bottom up' approach as an alternative to State (top down) development. Over recent years, however, successive New Zealand governments have embraced neoliberal social policies that have marginalised community development. In addition the term 'community work' has been used to describe activities that have little to do with a bottom up approach thereby making it difficult to define both community development and community work. By applying a 'knowledge intersections' schema to two New Zealand community and voluntary organisations we identify where community development and social work intersect. From this basis we challenge social workers to consider ways in which community development can be embedded within their practice.
\end{abstract}

\title{
Introduction
}

In this article we examine community development practice within the context of social services provided by the community and voluntary sector and identify ways that social workers can re-embed community development within their practice while also resisting the 
dominant neoliberal political discourse. Broadly speaking community development is held up as a way of working with communities that has a bottom up approach, as an alternative to State (top down) development. Over recent years, however, New Zealand government has embraced neoliberal social policies that have marginalised community development. In addition the term 'community work' has been captured by government agencies to describe activities that have little to do with a bottom up approach thereby making it difficult to identify what is community development or community work.

We define the terms community development and community work as two sides of the same idea. We use the following definition for community development:

Community Development is a participatory process of collective action to identify and address community needs that promote social justice, self determination and may also exert influence on decision makers (Aimers, 2011).

Community development can occur in a number of settings, such as geographic communities, communities of interest or even within single organisations.

The practice of community work facilitates community development. Community work uses skills such as group facilitation, networking, negotiation and an awareness of class, gender and cultural issues. In addition, community work practice utilises particular processes and techniques such as needs analysis, structural analysis, environmental scans, participatory action research, organisational planning, political lobbying, community consultation, mediation, collective decision making, cultural awareness training and caucusing.

This article begins with a discussion of the context within which community development is practised in New Zealand, focusing particularly on the influence the government has on community development practice and the wider community and voluntary sector. We follow with arguments for contemporary community development practice as an intersection of knowledges and introduce a schema for identifying and understanding these intersections. We then apply our schema to two community and voluntary sector organisations and conclude with a discussion of how social work practice can have a role in re-embedding community development practice in order to resist the dominance of the neoliberal environment.

\section{Neoliberalism and community development}

The evolution of community development practice in New Zealand over the last 30 years follows a similar path to that of the UK and Australia. Since the early 1980s, market-driven and neoliberal government policies have had a profound effect on the relationship between the community and voluntary sector and the state. These policies have created a widening gap between larger community and voluntary organisations providing government contracted social services and those smaller independent community organisations that have not been part of this partnering process (Tennant, O'Brien, \& Sanders, 2008). It is within these smaller organisations that the vestiges of bottom-up community development practices that were prevalent in the 1970s and early 1980s have remained.

The exception to this is for Māori where community development tends to focus on two main orientations, iwi (traditional tribal linkages) living in their own tribal area, and mata 
waka (Māori people living away from their own area that form connections with other Māori in that new area). Thus such commuinity development practice is iwi (or locality) orientated within Māori ethnicity (Walker, 1990; Eketone, 2006; Walker, 2007). However, neoliberal policies have had a significant effect on Māori as government responsibilities and resources previously controlled by the Department of Māori Affairs were devolved across government departments and to iwi. While this process created a greater awareness of the needs of Māori by many non-Māori it also provided many challenges for Māori organisations. One commentator estimated the growth in Māori social service providers from almost zero to 1,000 in the 20 years from 1984, creating a myriad of challenges including tensions between new providers and traditional tribal authorities (Tennant et al., 2008).

In recent years the terms 'community development' or 'community work' have become associated with, and indeed captured by, a wide range of activities from correctional sentences to 'work for the dole' schemes that have little to do with a bottom up approach leaving community development/work a pluralist concept. Government resources to support community development have gradually changed into guidelines to organisational best practice for community organisations, with very little information on either the theoretical or practical aspects of community development practice (Aimers \& Walker, 2009a).

The current position of bottom up style community development practice in New Zealand is predominantly within the community and voluntary sector, where both central and local government focus their resources to provide funding and support for capacity building. While a few territorial local authorities (TLA) were once very active in community development, their statutory role remains vague, promoting social, cultural, environmental and economic well-being (Local Government NZ, 2008). Like central government, TLAs have focused on partnerships with communities supporting community networks, championing the need for central government resources to their locality, providing small grants to community and sports groups and supporting central government initiatives to improve community/state relationships such as Safer Community Councils, Strengthening Families and Road Safety co-ordination (Aimers, 2005). Strengthening the community and voluntary sector's relationship with the state has been an important government initiative since the introduction of a Third Way-style variant of neoliberalism policies in the late 1990s. The resulting engagement in state-community partnerships to help create social capital and cohesion has been well documented (Larner \& Butler, 2005; Larner and Craig, 2005), resulting in initiatives such as the 'Pathway to Partnership' strategy. Introduced in 2007, Pathway to Partnership intended to 'build stronger, sustainable and more effective community-based social services for families, children and young people' (Ministry of Social Development, 2008). This strategy detailed how the government intended to work with community groups to deliver 'high quality' services and early support to families, children and young people. While community development work is still supported by a limited number of government grants, the focus of funding has become contracted direct provision of social services. The government's desire was not only to fund services but also to ensure that services are provided by organisations that reflect the same professional values and accountabilities as the government aspires to provide (Aimers \& Walker, 2008; Tennant et al., 2008). The Office of the Community and Voluntary Sector reports that in 2009 there were 18,860 organisations providing community development, housing or social services. Of these, only $12 \%$ employed staff. Given that Family and Community services contracts provide funding for only 600 organisations, this means that only a small percentage of all social service-based organisations are benefitting from 'high trust' relationships with the government (OCVS, 2010). 
Paradoxically, despite there being many state initiatives to support partnering with the community and voluntary sector, there has been a narrowing of government funding priorities to only fund those services that meet government priorities. This has resulted in the demise or re-structuring of a number of support and funding schemes that were focused on assisting and facilitating communities to define their own priorities and programmes such as Community Employment Group (CEG) and the Community Organisations Grants Scheme (COGS). The loss of CEG funding removed approximately $\$ 6.5$ million from 350 projects annually. For the COGS scheme, the change related to a shift in the power of decision making by restructuring COGS accountability processes away from the community to a more centralised and standardised arrangement. These changes have impacted on community development organisations the hardest and are an expression of state hegemony through funding processes that set the methods, practices, terms and control at a central level (Aimers and Walker, 2008).

A2010/11 survey of 234 non-profit organisations in New Zealand found that the most pressing concerns for the sector were related to funding in some form or other, e.g. increasing fundraising, reducing costs or concerns over government effects on funding (Thornton, 2011).

Not only is funding scarce, but the state partnering ethos has also diluted the local community's ability to engage in activisim, pushing those who do seek an oppositional or independent stance to be marginalised with regard to funding (DeFilippis, Fisher, \& Shragge, 2009; Aimers \& Walker, 2008).

\section{The role of community development within social work}

Community development has long been a part of the social worker's education and is recognised as the place where social workers can work on social justice issues. There are arguments that locate community development as one method of social work intervention and others that argue that it is a separate discipline (Kenny, 2011). In a survey of Australian social work programmes, Mendes (2009) found that community development sat at the margins despite being described as a core subject. In New Zealand there are six Bachelor of Social Work programmes offered in four universities and one polytechnic offering community development as part of their courses, these vary in level from second to fouth year courses. In two cases community development is combined with social development, while the remaining teach community development. Only one tertiary institution offers a community development specialty, as part of a Bachelor of Social Practice (Community Development).

Many argue that while there are inherent conflicts between community development and social work that separate them as disciplines, they are still linked by a shared interest in social justice (Mendes, 2009; Beddoe \& Maidment, 2009). Such differences include a micro-focus versus a meso- or macro-focus, planned intervention versus collective action and the power relations that exist between the professional paid worker versus local (often volunteer) leadership.

Social work can be defined as 'professional intervention to address situations of personal distress and crisis by shaping and changing the social environment in which people live' (Mendes, 2009, p.250). While planned intervention is integral to social work, the term sits 
uneasily in the realm of community development. Professionalism is another issue that may arise for the social worker engaged in community development practice. Social work is a recognised profession and, as a result, qualifications and experience may create power imbalances that affect the community response to social worker-led community work. This is particularly relevant in an environment that encourages the community and voluntary sector to engage in 'capacity building' and professionalise its activities in order to meet government requirements for contracting. An example of this can be seen in the development of women's organisations that moved from consciousness raising to service providers. Researchers found that as the role of professional staff grew, the ability for volunteers to engage with the organisation diminished, often being corralled into support roles and/or no longer being encouraged to develop and lead their own projects (Grey, 2009; Vanderpyl, 2004). While leadership and group development is integral to community development, these skills are not directly linked to formal qualifications or professional experience. Social workers wishing to engage in community development work must be vigilant to the power that their professional standing gives them and be mindful of the effect this may have on group dynamics (Bamford, 1990). Natural leadership should be encouraged from within a community and can develop without formal training:

An activist community development worker derives power from organizational knowledge and networking skills, rather than credentials (Kenny, 2011, p.401).

Kenny (2011) argues that professionalism and activism can work well together as funding requirements can restrict activism, however the presence of the professional may be able to mediate this to some extent.

The desire for planned interventions by professionally trained staff is mirrored in neoliberal government social policy discourse and funding. This is seen in government requirements for organisations to plan for specific outcomes and to build the 'capacity' of organisations in order to ready them as suitable service providers. Those services or organisations that wish to work in a different way are pushed to the margins, unfunded and isolated from governmental processes.

Community development is predominantly concerned with the wider environment and as such the felt needs of a community may go beyond what is traditionally thought of as the scope of social work practice. However social workers need to be aware of the value of addressing local needs, be they considering urban planning, transport, the natural environment or provision for recreation and leisure. All these impact on the health and wellbeing of the community and success in affecting change is a powerful tool for achieving personal and community empowerment.

\section{Knowledge intersections}

While it would be easy to think that community development is inherently radical and social work inherently conservative this is not the case. There are numerous examples of community development projects that support the dominant discourse and are not inclusive of those on the margins of their communities. There are also examples of social work practice that is challenging and empowering (Mendes, 2009; Beddoe \& Maidment, 2009). It is not without cause, therefore, that the definition of the terms 'community' and 'community development' have always been, and continue to be, hotly debated. It has been argued that community 
development can be parochial (Kenny, 2011) or be used as a tool of social control to create a homogonous community (Shaw, 2006). Sihlongonyane (2009) argues that the term community development has become so caught in multiple meanings that it is now little more than a 'rhetorical gesture' that can mean anything any interested group wants it to mean.

Conflicting definitions can result in state hegemony, paralysis and / or inaction, Shannon and Walker (2009) argue that community development requires attention to process; requiring inclusion of a wide a range of stakeholders to ensure that one voice does not dominate but all share in the articulation of issues and solutions. Localised community organisations are able to be concrete representations of community solutions and opportunities. By using the notion of knowledge intersections we can overcome this paralysis in definition by describing the intersections between community development and social work as a way to enhance the effectiveness of both practices.

The idea of mapping knowledges is one way to make sense of multiple meanings (Opie, 2000; Beddoe \& Maidment, 2009). Opie focuses on nodes of knowledge intersection where the team is able to work within the initial informational input to reconstitute their knowledges in modes other than the parallel narratives (where one powerful discourse dominates) in which they were first articulated. We believe that this analysis can be easily applied to community development and social work seeking knowledge intersections or nodes between each discipline.

We use the following schema (Aimers \& Walker, 2009a) to analyse two community and voluntary sector organisations. To consider the interactive process between ideas and politics; traditions, purpose and interests; visions and future and finally barriers to self-determination. The rationale behind this schema was to create a framework to describe community development and identify potential sites for engagement in and around other social development practices. By considering where the various practices of an organisation intersect the schema allows organisations to gain a wider perspective in order to identify the aspects of their work that have the potential to intersect with community development interests and apply community work practices.

Figure one. Community development knowledge intersections schema elements.

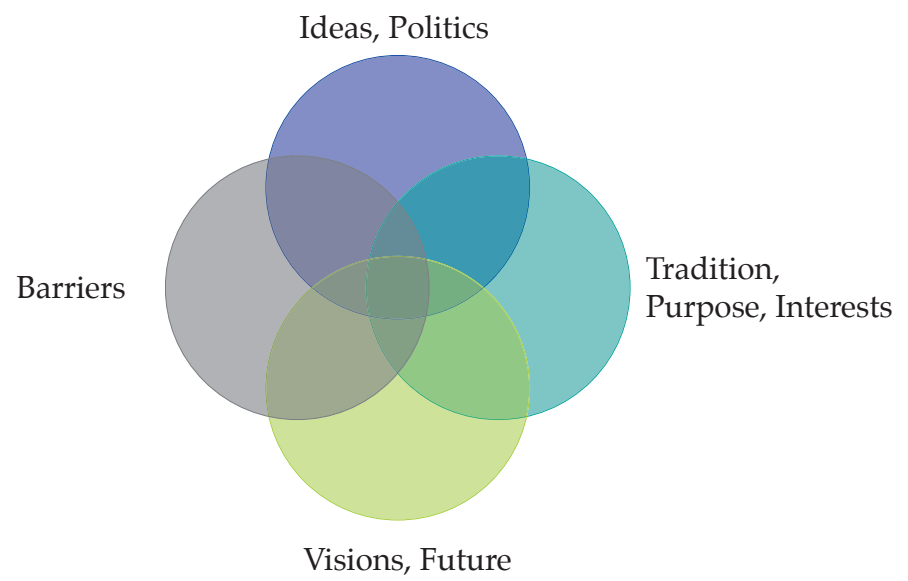


Thus the knowledge intersections schema consists of:

- Ideas, Politics - incorporating macro environmental concerns and meso responses to their environment

- Tradition, Purpose, Interests - is meso focused incorporating the mission, origins, internal relations of the organisation e.g. new vs traditional

- Vision, Future - their hopes and plans and how these are put into action

- Barriers - what may prevent them from achieving their vision.

\section{Case studies}

The data for these case studies was derived from a narrative research project, Structures and Strategies, undertaken in 2003 and repeated in 2008 (Aimers \& Walker, 2009b). Our method for distilling these summaries was to analyse the original narratives for each organisation and group sections from each narrative under the most appropriate schema heading to capture the key points. We acknowledge that this process may be coloured by our bias as researchers, however to balance this we have provided a selection of quotes from which we interpreted the following summaries. In addition, readers can access the full narratives in our Structures and Strategies Revisited monograph (Aimers \& Walker, 2009b).

For this paper we are featuring two of these case studies:

- Anglican Family Care (previously Anglican Methodist Family Care Centre) is an ecumenical organisation originating from a coalition of church-based organisations. It is one of many church-based social service organisations which were among the first social service agencies established in New Zealand. Formal arrangements were made between the Methodist and Anglican churches to combine their social services, and in 1970 the Anglican Methodist Family Care Centre was opened. Recently the Methodists withdrew from the partnership and the organisation was renamed Anglican Family Care. The main focus of their work is the provision of family-based social services.

- Arahina House is a local neighbourhood house in Mosgiel - a semi-rural community close to Dunedin. The original purpose, identified by local social service and health professionals, was to provide a base for social support, children's after-school, holiday and adult living skill programmes open to all, but aimed at, single parent and low income families. These programmes still remain the core activities but have become more intervention driven over recent years. At the time of the second interview the management of Arahina House was about to be transferred from a small local committee to a larger Social Service organisation, the Methodist Mission.

It should be noted that we are analysing these two case studies to show the workings of the knowledge intersections schema rather than being an exhaustive analysis of these two organisations.

\section{Anglican Family Care}

\section{Ideas/politics}

AFC started as a church-based organisation with all their funding and direction setting provided by both the Methodist and Anglican Church communities at a local level. How- 
ever with government funding grants and new philosophies espoused in child protection legislation these localised efforts changed to align with government priorities.

...in 1970 the Anglican Methodist Family Care Centre was opened. Board membership was half Methodist and half Anglican.

When the agency started, all funding came from the churches. They paid for the entire operation up till the early 1980s. When the government started offering grants to organisations doing family work, these organisations then started to grow. Then the Children, Young Persons and Their Families Act set up new structures and increasing government money flowed through to the non-government sector. Nowadays we receive about five percent of our income from the churches (pp. 7-11).

\section{Traditions/purpose/interests}

With the introduction of contracted funding, the traditional purpose changed to focus on a business model in line with neo-liberal policies at a state level. This change introduced a tighter, more business-focused governance and also a huge expansion of staff to meet the contract provisions.

The growth in funding proved to be problematic with systems straining to cope with the growth of AFC. The complexity of problems and seriousness of issues facing the AFC workers has increased. This has led to a need to employ higher-qualified workers or upskilling in-post workers. In addition cultural knowledges have expanded as AFC meet the needs of a more diverse clientele. This has involved the need to build partnerships with the Māori and Pacific people communities.

Anglican Methodist Family Care began with two staff. Now we have 47 and we are one of the biggest contractors with Child, Youth and Family in New Zealand ... In terms of our social services all the staff report that the nature of the issues people are coming to us with is escalating in their complexity and difficulty and seriousness ... We now have a very qualified workforce, pretty much all of them are either tertiary-qualified or working towards a qualification and they are doing high-risk work (pp. 7-11).

\section{Vision/future}

The vision has shifted over the six years from an independent one-stop shop for families to a more networked approach amongst the largest agencies to better deliver services and lobby for change at a policy level.

\section{Barriers}

The main barriers identified were how to meet local needs not covered by contracts and how to work within the contracts to provide services when the need is expanding but the funding environment is getting tighter and more competitive.

... we find it difficult when we see needs and are unable to address them. Money from the churches in the past enabled us to attend to the needs. It is a challenge for us as an agency when we identify needs that we are unable to secure funding for ... I'm looking now at how can we rationalise everything, and not drop jobs, and try and fit within the funding we've got. Because finding other sources of money is difficult (pp. 7-11). 


\section{Arahina House}

\section{Ideas/politics}

Arahina house is in many ways a classic example of a neighbourhood community house. It was established as a safe environment for women and children to learn skills and meet together, provide networks and supports. More recently the types of programmes have moved more to a case management model than purely self-help support.

The Arahina Community House initiative grew out of a need identified by the local Multi-disciplinary Co-ordinating Group...Stability, continuity and security are things we try to provide which makes the house a safe place for people to be, for some clients it is the only place they experience any of these concepts.

We have a lot of people coming in off the street, it's more like a family support centre now, word is finally getting out there that Arahina is a place where you can go and you can ask for help (pp. 7-11).

\section{Traditions/purpose/interests}

Arahina started out as a focus of community education courses and holiday programmes based on a community development self-help ethos. Funding accountability requirements mean programmes have moved to an outcomes-based model, requiring a more professional intervention approach.

... because we had contracts with MSD, FACS and CYFS, they required us to deliver specific programmes in the specific way and that we were accountable for that. There was a little bit of resistance from the trustees because historically ... they were quite resistant to that government focus of making us change to fit them, when really we were about the community ... (pp. 7-11).

\section{Vision/future}

Arahina wish to expand the number of programmes and employ more staff to cover this expansion.

I think Arahina could deliver a lot more and better, if we had funding. We don't have enough funding to cover our staff as it is now. Not very many places will cover tutor wages or coordinator wages ... At the moment we are lucky because we get people that come in and just volunteer their time. But I think with the expertise that we are using from those volunteer people, we really need to pay them... (pp. 7-11).

\section{Barriers}

As with other groups, funding and accountability compliance are the biggest barriers identified by Arahina.

I'm quite fearful of the funding. It just runs my life to be honest; it's there the whole time. With funding, you just about need a full-time funding adviser. Funding is such a huge issue for us. We make do with less, we really do, we stretch everything out to the last ... as far as the accountability, it's a huge amount of paperwork; and the paper work is just becoming overbearing to be honest (pp. 7-11). 
Table one. Community development intersections schema.

\begin{tabular}{|c|c|c|c|c|}
\hline Groups & Ideas/politics & Traditions/purpose/interests & Visions/future & Barriers \\
\hline $\begin{array}{l}\text { Anglican } \\
\text { Family } \\
\text { Care }\end{array}$ & $\begin{array}{l}\text { Originally } \\
\text { church } \\
\text { welfare model } \\
\text { but as more } \\
\text { government } \\
\text { funding } \\
\text { became } \\
\text { available the } \\
\text { services became } \\
\text { more dictated } \\
\text { by government } \\
\text { priorities. }\end{array}$ & $\begin{array}{l}\text { Rapid growth and changes in } \\
\text { organisational style to fit with } \\
\text { contracting model, latterly } \\
\text { feeling a need to reduce rapid } \\
\text { growth and consolidate. } \\
\text { Original church partnership } \\
\text { was dissolved } \\
\text { More complex needs needing } \\
\text { a professionally trained } \\
\text { workforce. } \\
\text { Increased awareness of the needs } \\
\text { of Māori and Pacific peoples. }\end{array}$ & $\begin{array}{l}\text { Changed from } \\
\text { wanting to be } \\
\text { a one-stop shop } \\
\text { to working more } \\
\text { co-operatively } \\
\text { with } \\
\text { other agencies. }\end{array}$ & $\begin{array}{l}\text { Dependence on } \\
\text { government } \\
\text { funding } \\
\text { restricts the } \\
\text { ability to } \\
\text { respond } \\
\text { directly to } \\
\text { community } \\
\text { needs. } \\
\text { Short-term } \\
\text { funding and } \\
\text { time taken } \\
\text { in funding } \\
\text { compliance. }\end{array}$ \\
\hline $\begin{array}{l}\text { Arahina } \\
\text { House }\end{array}$ & $\begin{array}{l}\text { Set up to } \\
\text { provide a safe } \\
\text { secure } \\
\text { environment for } \\
\text { women and } \\
\text { children to } \\
\text { learn skills }\end{array}$ & $\begin{array}{l}\text { Began as a self-contained } \\
\text { provider of group programmes } \\
\text { to which a referral agency with } \\
\text { a focus on individual } \\
\text { assessment has been added. }\end{array}$ & $\begin{array}{l}\text { Grow } \\
\text { programmes } \\
\text { and staff, be } \\
\text { in a position } \\
\text { to employ more } \\
\text { staff rather } \\
\text { than rely on } \\
\text { volunteers for } \\
\text { extra assistance. }\end{array}$ & $\begin{array}{l}\text { Lack of } \\
\text { funding and } \\
\text { the demands } \\
\text { of funding } \\
\text { compliance. }\end{array}$ \\
\hline
\end{tabular}

Our two case studies are typical of many medium to large social service agencies that run on a mixture of government contracts, philanthropic grants and fundraising/donations. Funding is a considerable driver for such organisations, with very little funding available to pay salaries other than via government contracts; this limits the ability of organisations to take any other path than either a contracted service provider or independent volunteer organisation. This is particularly relevant for medium-sized organisations like Arahina, who have grown out of the community but now find that funding pressures and contracting have altered their focus. This leads to a juggling of priorities and a tension between local and central obligations, with some organisations trying to work with both their communities' felt needs alongside their contract obligations.

\section{Conclusion: Intersections between social work and community development}

Social work educators and social workers recognise the value of community development practice for affecting change at an organisational or community level. However, the case studies outlined illustrate the bind that social workers find themselves in limited by the government-funded programmes that utilised social work practice rather than 'bottom up' community development work. We believe that this is not from lack of intention but 
due primarily to the case study organisations' dependence on government funding. This dependence limits organisations to only responding to government priorities set by the contracting environment. The challenge, therefore, is for organisations to maintain the links with their original vision and with their communities, creating space for those communities to voice dissent or provide input on programme direction or content. However this may be a challenge for organisations that become deeply involved in the partnering-up process as they are understandably supportive of any initiative that will give them greater funding security (Jenkins, 2005; Larner and Craig, 2005).

We believe that the knowledge intersections schema outlined in this article is a useful tool to analyse the organisational response to community development. It is hoped that such a schema will allow a repositioning of community development practices within community and voluntary sector organisations in order that the voice of their communities gains agency and power that ultimately feeds back into government policies.

While this process cannot be prescribed we offer some suggestions for approaching it. For example social workers within organisations like Family Care or Arahina could utilise the schema to identify spaces from which to incorporate more community development practice in their programmes, such as:

1. Looking for ways to incorporate the needs and desires of their communities rather then risk the situation where one narrative - that of the funder, or the policy maker or the professional - dominates. This could be achieved by seeking alternative localised direction-setting accountability relationships to broaden the range of stakeholders and accountability relationships. Such mechanisms could include dual accountability mechanisms whereby organisations actively seek community input through community accountability days in addition to community representation on governance committees.

2. Create alliances with smaller localised activist groups to help them gain leverage resources for local issues. Such alliances and partnerships could focus on community development programmes that the larger organisation cannot due to contract requirements and/or constraints.

3. Use untagged funding from donations or other philanthropic sources that are not subject to government accountabilities to initiate and support community development projects that are activist based and led by community leaders rather than interventions by professionals.

For community development to continue to have traction in New Zealand, we need to find ways of allowing groups to respond to local community needs in a wide range of ways. Neoliberal thinking has narrowed funding opportunities and forced community and voluntary sector organisations to confirm to a 'one size fits all' organisational profile. Social workers have an important role in exploring ways to incorporate community development in their work. By seeking out the potential for social work to intersect with community development, social workers can ensure that they can facilitate sustainable and long-term change for their clients and for their communities.

\section{References}

Aimers, J. (2005). Developing community partnerships: Social wellbeing and the Local Government Act 2002. Social Work Review, XVII(3), 34-40. 
Aimers, J. (2011 in press). The impact of NZ third way style government on women in community development. Community Development Journal, Special Issue 'The Politics of Everyday Life: Feminisms and Contemporary Community Development, Summer.

Aimers, J., \& Walker, P. (2008). Is community accountability a casualty of government partnering in New Zealand? New Zealand Social Work Review, XX(3), 14-24.

Aimers, J., \& Walker, P. (2009a). Community development as 'knowledge intersections' in contemporary New Zealand. Community Development Journal International Symposium, September.

Aimers, J., \& Walker, P. (2009b). Structures and strategies revisited 2008: A comparative storying of five social service and community support organisations in Otago, New Zealand. Monograph, University of Otago. 69 pages. http: / / www. communityresearch.org.nz/ resources.php?view=1173.

Bamford, T. (1990). The future of social work. Basingstoke: Macmillan.

Beddoe, L., \& Maidment, J. (2009). Mapping knowledge for social work practice, critical intersections. Australia: Cengage Learning.

Community Employment Group. (2002). Evaluation of the Community Employment Group's Community Employment Initiatives. Unpublished report.

Department of Internal Affairs. (2006). The Community Development Resource Kit. Retrieved 4 May 2009 from www. community.net.nz/how-toguides/crk.

Department of Internal Affairs. (2008). Ministerial briefing papers. Retrieved 1 May 2009 from http: / / www.beehive. govt.nz/sites/all/files / DIA_BIM.pdf.

DeFilippis, J., Fisher, R., \& Shragge, E. (2009). What's left in the community? Oppositional politics in contemporary practice. Community Development Journal, 44(1), 38-52.

Eketone, A. (2006). Tapuwae: A vehicle for community change. Community Development Journal, 41(4), 467-480.

Grey, S. (2009). Women, politics and protest: Rethinking women's liberation activisim in New Zealand. In K. McMillan, J. Leslie \& E. McLeay (Eds.). Rethinking women and politics: New Zealand and comparative perspectives (pp. 34-61). Wellington: Victoria University Press.

Healy, T. (2004). Social capital: Some policy and research implications for New Zealand. Research Paper, Institute of Policy Studies, Victoria University, Wellington. Retrieved 16 May 2009 from http:/ /ips.ac.nz/ events/downloads / Tom $\% 20$ Healy $\% 20$ social $\% 20$ capital $\% 20$ report $\% 20 I P S \% 202004$.pdf.

Healey, P., de Magalhaes, C., Kadanipour, A., \& Pendlebury, J.. (2003). Place, identity and local politics: Analysing initiatives in deliberative governance. Deliberative policy analysis (pp. 60-87). Cambridge: Cambridge University Press.

Jenkins, K. (2005). No way out? Incorporating and restructuring the voluntary sector within spaces of neo-liberalism. In N. Laurie and L. Bondi (Eds). Working the spaces of neo-liberalism (pp. 216-221). Blackwell Publishing.

Kenny, S. (2011). Developing communities for the future (4th ed.) Melbourne, Australia: Cengage Learning.

Larner, W., \& Butler, M. (2005). Governmentalities of local partnerships: The rise of a 'partnering state' in New Zealand. Antipode, 37(3).

Larner, W., \& Craig, D. (2005). After neo-liberalism? Community activism and local partnerships in Aotearoa New Zealand. Antipode, 37(3), 402-424.

Local Government New Zealand. (2008). Role of local government. Retrieved 4 May 2009 from http:/ / www.lgnz. co.nz/lg-sector/role.

Mendes, P. (2009). Teaching community development to social work students: A critical reflection. Community Development Journal, 44(2), 248-262.

Ministry of Social Development. (2008). New funding for NGO sector as part of Pathway to Partnership. Retrieved 20 February 2008 from http:/ / www.msd.govt.nz/media-information/press-releases/2008/ pr-2008-02-12.html.

Office of the Community and Voluntary Sector (OCVS). (2010). Retrieved November 2010 from www.ocvs.govt. nz.

Opie, A. (2000). Thinking teams/thinking clients: Knowledge-based teamwork. New York: Columbia University Press.

Shannon, P., \& Walker, P. (2009). Partnerships and control: Lessons from a research programme into strategies for deliberative governance. Community Development Journal Symposium, London.

Shaw, F. (2006). Community development and the politics of community. Community Development Journal, 43(1), 24-36.

Sihlongonyane, M. F. (2009). Community development as a buzz-word. Development in Practice, 19(2), $136-147$.

Tennant, M., O'Brien, M., \& Sanders, J. (2008). The history of the non-profit sector in New Zealand, Office for the Community and Voluntary Sector. Retrieved 12 May 2009 from http://www.ocvs.govt.nz/documents/publications / reports / the-history-of-the-non-profit-sector-in-new-zealand.pdf.

Thornton, G. (2011). New Zealand not for profit survey 2010/11. Retrieved 20 April 2011 from http:/ / www.grantthornton.co.nz/ Assets / documents / home/NFP-report-2011-2012.pdf.

Vanderpyl, J. (2004). Aspiring for unity and equality: Dynamics of conflict and change in the 'by women for women' feminist service groups, Aotearoa/New Zealand (1970-1999). unpublished PhD thesis, University of Auckland.

Walker, P. (2007). Trust, risk and control in an indigenous-non-indigenous social service partnership. International Journal of Social Welfare, 16(3), 281-290.

Walker, R. (1990). Ka whawhai tonu matou: Struggle without end. Auckland: Penguin Books. 